Revista Eletrônica de Direito Processual - REDP.

Rio de Janeiro. Ano 10. Volume 17. Número 2. Julho a Dezembro de 2016

Periódico Semestral da Pós-Graduação Stricto Sensu em Direito Processual da UERJ

Patrono: José Carlos Barbosa Moreira. ISSN 1982-7636. pp. 377-405

wWw.redp.uerj.br

\title{
A IDENTIFICAÇÃO CRIMINAL PELO DNA EM FACE DA GARANTIA \\ CONTRA A AUTOINCRIMINAÇÃO'
}

\section{THE CRIMINAL IDENTIFICATION BY DNA, CONCERNING THE PRIVILEGE AGAINST SELF-INCRIMINATION}

Juliana Leonora Martinelli Giongo

Pós-graduanda no Curso de Especialização em Ciências Penais pela Pontifícia Universidade Católica do Rio Grande do Sul. Advogada. Porto Alegre, Rio Grande do Sul, Brasil.

juliana_giongo@hotmail.com

RESUMO: Este artigo se propõe a analisar a Lei n. $^{\circ}$ 12.654/2012, que, dentre outras modificações, acrescentou uma nova forma de identificação criminal: por meio do DNA. Inicialmente, estudar-se-á a possibilidade de os investigados e de os acusados serem submetidos, mesmo sem consentimento, à extração de seu material biológico. Discutir-seá, então, após uma análise da abrangência dada, em território nacional, à garantia contra a autoincriminação, se a Lei n. ${ }^{\circ}$ 12.654/2012 não acabou por afrontar tal garantia. Por fim, sendo o resultado final a confecção de uma prova genética, serão efetuadas algumas considerações acerca da confiabilidade no exame de DNA.

PALAVRAS-CHAVE: Lei 12.654; DNA; nemo tenetur se detegere; garantia contra a autoincriminação; processo penal.

ABSTRACT: This article aims to analyze the Law 12.654/2012, which, among other changes, added a new form of criminal identification: by DNA. Initially, we will study the possibility of the investigated and the defendant be submitted, even without consent, to the extraction of their biological material. After analyzing the scope given in Brazil to the

\footnotetext{
${ }^{1}$ Artigo recebido em 31/08/2016 e aprovado em 18/10/2016.
} 
Revista Eletrônica de Direito Processual - REDP.

Rio de Janeiro. Ano 10. Volume 17. Número 2. Julho a Dezembro de 2016

Periódico Semestral da Pós-Graduação Stricto Sensu em Direito Processual da UERJ

Patrono: José Carlos Barbosa Moreira. ISSN 1982-7636. pp. 377-405

wWw.redp.uerj.br

privilege against self-incrimination, we will discuss if the Law 12.654/2012 does not eventually confront such privilege. Finally, since the final result is a production of a genetic proof, we will consider the reliability of DNA exam.

KEYWORDS: Law 12.654/2012; DNA; nemo tenetur se detegere; privilege against selfincrimination; criminal process.

\section{INTRODUÇÃO}

Este artigo tem por objetivo analisar a Lei n. ${ }^{\circ} 12.654 / 2012$, notadamente na parte em que trata da extração de perfil genético dos investigados e dos acusados, a fim de identifica-los criminalmente, confrontando tal prática com a garantia contra a autoincriminação, também conhecida como princípio do nemo tenetur se detegere. Esse confronto se torna necessário, pois o diploma legal estudado autorizou que a coleta do material biológico do imputado seja executada inclusive sem o consentimento dele, ignorando que, após a extração do DNA, caso exista compatibilidade entre o material colhido e o material encontrado na vítima ou no local do crime, haverá confecção de perícia, que é um meio de prova conhecido.

O exame de DNA, por sua natureza científica, possui alta receptividade no âmbito jurídico, obviamente influenciando, e muito, a opinião do julgador; entretanto, é imprescindível recordar que tal prova é apenas mais uma, não podendo, por si só, sustentar uma sentença condenatória, porquanto pode conter erros, levando a resultados inverossímeis, que podem gerar condenações indevidas. Ao final, então, serão trazidas algumas questões acerca da confiabilidade na prova genética.

\section{IDENTIFICAÇÃO CRIMINAL NAS FASES PRÉ-PROCESSUAL E PROCESSUAL: AS ALTERAÇÕES OCORRIDAS COM A PROMULGAÇÃO DA LEI N. ${ }^{\circ} 12.654 / 2012$}

A Lei n. ${ }^{\circ}$ 12.654, de 28 de maio de 2012, com entrada em vigor em 28 de novembro do mesmo ano, inovou no sistema jurídico nacional, uma vez que estabeleceu, 
Revista Eletrônica de Direito Processual - REDP.

Rio de Janeiro. Ano 10. Volume 17. Número 2. Julho a Dezembro de 2016

Periódico Semestral da Pós-Graduação Stricto Sensu em Direito Processual da UERJ

Patrono: José Carlos Barbosa Moreira. ISSN 1982-7636. pp. 377-405

www.redp.uerj.br

pela primeira vez, a coleta de material biológico para a obtenção de perfil genético como forma de identificação criminal, além de trazer as diretrizes para a criação do banco de dados de perfis genéticos.

Com efeito, a identificação criminal é abordada, inicialmente, na Constituição Federal, no artigo $5^{\circ}$, inciso LVIII, trazendo a seguinte redação: "o civilmente identificado não será submetido a identificação criminal, salvo nas hipóteses previstas em lei”. A ressalva constante na Carta Magna ocasionou a publicação da Lei n. ${ }^{0}$ 10.054/2000 e, posteriormente, com a revogação dessa última, da Lei n. ${ }^{\circ} 12.037$ em $2009^{2}$.

A Lei n. ${ }^{o}$ 12.037/2009, em sua redação original, trouxe a possibilidade de identificação criminal do civilmente identificado por meio do processo datiloscópico e do fotográfico, e tão somente destes. As hipóteses para tal identificação, por sua vez, previstas no artigo $3^{\circ}$ da mencionada legislação, são: (a) quando o documento de identificação civil apresentado conter rasura ou tiver indício de falsificação; (b) quando o documento apresentado for insuficiente para identificar cabalmente o indiciado; (c) quando o indiciado portar documentos de identidade distintos, com informações conflitantes entre si; (d) se a identificação criminal for essencial às investigações policiais, segundo despacho da autoridade judiciária competente, que decidirá de ofício ou mediante representação da autoridade policial, do Ministério Público ou da defesa; (e) se constar de registros policiais o uso de outros nomes ou diferentes qualificações pelo indiciado; e, finalmente, (f) caso o estado de conservação ou a distância temporal ou da localidade da expedição do documento apresentado impossibilite a completa identificação dos caracteres essenciais.

Em 2012, promulgou-se a Lei n. ${ }^{\circ}$ 12.654, ora estudada, alterando a Lei n. ${ }^{\circ}$ 12.037/2009 e acrescentando a coleta de material biológico para a obtenção de perfil genético como forma de identificação criminal do civilmente identificado, porém apenas na hipótese referente ao inciso IV acima assinalado. Autorizou-se, assim, uma nova forma de identificação criminal.

Segundo o novo diploma, o material genético do indivíduo poderá ser extraído em duas situações diferentes, a fim de identificá-lo criminalmente: (a) na fase investigatória e

\footnotetext{
2 QUEIJO, Maria Elizabeth. O princípio nemo tenetur se detegere e a coleta de material genético: identificação criminal ou colaboração na produção da prova? Boletim IBCCRIM, São Paulo, ano 21, n. 250, p. 7, set. 2013 .
} 
Revista Eletrônica de Direito Processual - REDP.

Rio de Janeiro. Ano 10. Volume 17. Número 2. Julho a Dezembro de 2016

Periódico Semestral da Pós-Graduação Stricto Sensu em Direito Processual da UERJ

Patrono: José Carlos Barbosa Moreira. ISSN 1982-7636. pp. 377-405

www.redp.uerj.br

(b) na execução da pena. $\mathrm{O}$ ato atinge, consequentemente, tanto o investigado/acusado quanto os condenados. Não obstante, é notável que a intenção da coleta é diversa, dependendo da situação processual em que se enquadra: se a extração do perfil genético acontecer na fase investigatória, o DNA servirá de prova para um caso concreto e determinado, isto é, para um delito que já ocorreu; de outro viés, se a extração se der na execução da pena, o DNA, que se encontrará em um banco de dados genético, será útil para casos futuros, em que se desconheça a autoria criminosa ${ }^{3}$.

Destaca-se, destarte, que a promulgação da Lei n. ${ }^{\circ} 12.654 / 2012$ alterou dois institutos da processualística penal: o da identificação criminal, presente na Lei n. $^{\circ}$ 12.037/2009; e o da execução penal, consubstanciada na Lei n. ${ }^{\circ}$ 7.210/1984. Então, tendo como focos deste artigo as fases pré-processual e processual, com incidência da Lei de 2009, passa-se à análise da hipótese de identificação do investigado e do acusado.

Segundo o parágrafo único do artigo $5^{\circ}$ da Lei n. ${ }^{\circ} 12.037 / 2009$, combinado com o artigo $3^{\circ}$, inciso IV, do mesmo diploma, a novatio legis autorizou a possibilidade do investigado e do acusado, civilmente identificados, fornecerem o seu material genético para se proceder à identificação criminal, quando tal medida for essencial às investigações policiais e existir decisão judicial nesse sentido, independentemente do delito apurado.

Reforça-se que a coleta do DNA, nessa situação, acontece em momento específico: nas fases pré-processual ou processual, ocasiões em que os princípios do nemo tenetur se detegere e da presunção de inocência têm plena aplicabilidade ${ }^{4}$.

Quanto ao critério que define as hipóteses em que a identificação genética será empregada, qual seja, a essencialidade às investigações conforme autorização judicial fundamentada, tem-se que este é um critério subjetivo. O subjetivismo é aplaudido por Rafael Sauthier, que entende ser tal critério o mais adequado nessa etapa, permitindo uma melhor análise do caso concreto, a fim de decidir acerca da real imprescindibilidade da intervenção ${ }^{5}$. Nesse sentido, Eugênio Pacelli de Oliveira grifa que o juiz, ao averiguar a

\footnotetext{
${ }^{3}$ LOPES JR., Aury. Lei 12.654/2012: é o fim do direito de não produzir prova contra si mesmo (nemo tenetur se detegere)? Boletim IBCCRIM, São Paulo, ano 20, n. 236, p. 5, jul. 2012.

${ }^{4}$ SAUTHIER, Rafael. A identificação e a investigação criminal genética à luz dos direitos fundamentais e da Lei 12.654/12. 2013. 251 f. Dissertação (Mestrado em Ciências Criminais) - Faculdade de Direito, Pontifícia Universidade Católica do Rio Grande do Sul, Porto Alegre, 2013, p. 101-102.

${ }^{5}$ Ibid., p. 102 e 104.
} 
Revista Eletrônica de Direito Processual - REDP.

Rio de Janeiro. Ano 10. Volume 17. Número 2. Julho a Dezembro de 2016

Periódico Semestral da Pós-Graduação Stricto Sensu em Direito Processual da UERJ

Patrono: José Carlos Barbosa Moreira. ISSN 1982-7636. pp. 377-405

www.redp.uerj.br

real necessidade da coleta de DNA, deverá levar em consideração a natureza do delito praticado, além de sua gravidade ${ }^{6}$.

Rafael Sauthier explica, ainda, que a decisão judicial fundamentada autorizadora da medida ocorrerá de ofício ou mediante provocação (da autoridade policial, do Ministério Público ou da defesa), podendo conter três objetos: (a) a determinação da identificação criminal do civilmente identificado; (b) a escolha da identificação genética como método de identificação criminal; e (c) a determinação de coleta coativa das amostras biológicas do imputado, em caso de negativa desse último ${ }^{7}$.

Já Aury Lopes Jr. assevera que o fornecimento do material biológico poderá ser voluntário ou coercitivo, mas sempre observado o emprego de técnica adequada e indolor ${ }^{8}$. $\mathrm{O}$ autor também apresenta a necessidade do emprego do princípio da especialidade no presente cenário, "limitando o nexo causal legitimante ao caso penal investigado", ou seja, o material biológico colhido apenas poderá ser utilizado na investigação que deu causa à medida e dentro do limite temporal determinado para a prescrição daquele crime ${ }^{9}$.

Por último, em relação à exclusão do perfil genético dos investigados e dos acusados do banco de dados em que ocorrer o armazenamento, nos termos do artigo $7^{\circ}$-A da Lei n. ${ }^{\circ} 12.037 / 2009$, criado pela Lei n. ${ }^{\circ} 12.654 / 2012$, tem-se que essa retirada apenas acontecerá no término do prazo legal estabelecido para a prescrição do crime. Aury Lopes Jr. e Maria Elizabeth Queijo, no entanto, são exemplos de doutrinadores que discordam de tal previsão legal ${ }^{10}$. Aury Lopes Jr. chega a opinar pela aplicação, por analogia, do artigo $7^{\circ}$ do primeiro diploma mencionado, que tem a seguinte redação: "No caso de não oferecimento da denúncia, ou sua rejeição, ou absolvição, é facultado ao indiciado ou ao réu, após o arquivamento definitivo do inquérito, ou trânsito em julgado da sentença, requerer a retirada da identificação fotográfica do inquérito ou processo, desde que apresente provas de sua identificação civil”. A única ressalva a essa posição é o caso do

\footnotetext{
${ }^{6}$ OLIVEIRA, Eugênio Pacelli de. Curso de processo penal. 17. ed. São Paulo: Atlas, 2013, p. 396.

${ }^{7}$ SAUTHIER, op. cit., p. 102.

${ }^{8}$ LOPES JR., Aury. Lei 12.654/2012: é o fim do direito de não produzir prova contra si mesmo (nemo tenetur se detegere)? Boletim IBCCRIM, São Paulo, ano 20, n. 236, p. 6, jul. 2012.

${ }^{9}$ LOPES JR., Aury. Direito processual penal. 10. ed. São Paulo: Saraiva, 2013, p. 635.

${ }^{10}$ LOPES JR., Aury. Lei 12.654/2012: é o fim do direito de não produzir prova contra si mesmo (nemo tenetur se detegere)? Boletim IBCCRIM, São Paulo, ano 20, n. 236, p. 6, jul. 2012; QUEIJO, Maria Elizabeth. O princípio nemo tenetur se detegere e a coleta de material genético: identificação criminal ou colaboração na produção da prova? Boletim IBCCRIM, São Paulo, ano 21, n. 250, p. 7, set. 2013.
} 
Revista Eletrônica de Direito Processual - REDP.

Rio de Janeiro. Ano 10. Volume 17. Número 2. Julho a Dezembro de 2016

Periódico Semestral da Pós-Graduação Stricto Sensu em Direito Processual da UERJ

Patrono: José Carlos Barbosa Moreira. ISSN 1982-7636. pp. 377-405

www.redp.uerj.br

arquivamento do inquérito policial, já que, conforme a súmula n. ${ }^{\circ} 524$ do Supremo Tribunal Federal, lida a contrario sensu, havendo novas provas, a ação penal poderá ser iniciada $^{11}$.

Ademais, sobre o aspecto da exclusão das informações, Maria Elizabeth Queijo elucida que o Decreto n. ${ }^{\circ}$ 7.950/2013, que institui o Banco Nacional de Perfis Genéticos e a Rede Integrada de Bancos de Perfis Genéticos, no seu artigo $7^{\circ}$, previu a possibilidade da dita exclusão se dar em data anterior à do término do prazo prescricional, definida em decisão judicial; não obstante, o dispositivo deixou ao arbítrio do juiz a definição, não conferindo nenhuma garantia ao sujeito identificado pelo material genético ${ }^{12}$.

Analisadas, portanto, as inovações trazidas pela Lei n. ${ }^{\circ}$ 12.654/2012 no que concerne à identificação criminal nas fases pré-processual e processual, é possível notar o quão particular é este diploma legal, responsável por modernizar a legislação processual penal, colocando-a no mesmo nível de outros ordenamentos jurídicos, que já possuíam a identificação genética há certo tempo. Entretanto, em que pese a boa intenção de atualização, a forma como a Lei em comento foi redigida deixa margem à discussão, pois trata de modo descuidado de um assunto que merece cautela, especialmente em decorrência da restrição de garantias fundamentais que efetua. Por isso, não se estranha que diversos autores apontem a violação ao princípio do nemo tenetur se detegere pela nova legislação, mas, como de costume, esse posicionamento não é uníssono. Cabe, então, após uma análise da abrangência dada, pela doutrina nacional, ao princípio citado, a exploração dos principais argumentos utilizados pelos doutrinadores tanto na defesa quanto na crítica à novatio legis, restringindo-se tal estudo ao âmbito do presente artigo, que é a identificação criminal genética dos suspeitos e dos acusados.

\section{A ABRANGÊNCIA DADA, PELA DOUTRINA NACIONAL, AO PRINCÍPIO DO NEMO TENETUR SE DETEGERE EM FACE DAS INTERVENÇÕES CORPORAIS}

\footnotetext{
${ }^{11}$ LOPES JR., Aury. Direito processual penal. 10. ed. São Paulo: Saraiva, 2013, p. 636.
}

${ }^{12}$ QUEIJO, op. cit., p. 7. 
Revista Eletrônica de Direito Processual - REDP.

Rio de Janeiro. Ano 10. Volume 17. Número 2. Julho a Dezembro de 2016

Periódico Semestral da Pós-Graduação Stricto Sensu em Direito Processual da UERJ

Patrono: José Carlos Barbosa Moreira. ISSN 1982-7636. pp. 377-405

wWw.redp.uerj.br

Nemo tenetur se detegere é a máxima latina para a garantia contra a autoincriminação ${ }^{13}$. Tal garantia está expressa no artigo 14, 3, “g”, do Pacto Internacional sobre Direitos Civis e Políticos e no artigo $8^{\circ}, 2$, "g", da Convenção Americana sobre Direitos Humanos. Os dois dispositivos possuem uma redação semelhante e trazem a ideia de que toda pessoa acusada por algum delito tem o direito de não ser obrigada a depor contra si mesma, nem a confessar-se culpada. No entanto, destaca-se que a garantia contra a autoincriminação também pode ser deduzida do devido processo constitucional e do estado de inocência (inciso LVII do artigo $5^{\circ}$ da Lei Maior) ${ }^{14}$.

Nereu José Giacomolli conceitua o nemo tenetur se detegere como sendo "o direito de não produzir ou colaborar na produção de quaisquer provas, sejam elas documentais, periciais ou outras”. Por isso, ninguém pode ser compelido, legitimamente, a produzir ou colaborar na produção de provas, autoincriminando-se, indo contra os seus interesses processuais, devendo ser respeitado o direito a não agir. Além disso, o autor defende que o direito ao silêncio é espécie da garantia, que é gênero, visto que, enquanto o primeiro abarca tão somente o direito do imputado de não declarar, a segunda engloba uma “complexidade de comportamentos, condutas, circunstâncias autoincriminatórias, não só a exteriorização do pensamento mediante declaração"15.

Destaca-se, no entanto, que o princípio-garantia ${ }^{16}$ do nemo tenetur se detegere, de âmbito constitucional, não é uma garantia fundamental absoluta, podendo ser restringida, quando em conflito com outros valores constitucionais, através da ponderação. Essa relativização do princípio não poderá eliminar o seu conteúdo essencial. A problemática, portanto, é saber qual o "conteúdo essencial" da garantia contra a autoincriminação: até que ponto é possível impor uma restrição sem afetar a finalidade da mesma?

Maria Elizabeth Queijo, dissertando acerca do assunto, refere que, apesar de o princípio do nemo tenetur se detegere não ter limitação constitucional expressa, os limites

\footnotetext{
${ }^{13}$ QUEIJO, Maria Elizabeth. O direito de não produzir prova contra si mesmo: o princípio nemo tenetur se detegere e suas decorrências no processo penal. 2. ed. São Paulo: Saraiva, 2012, p. 28.

${ }^{14}$ GIACOMOLLI, Nereu José. $O$ devido processo penal: abordagem conforme a Constituição Federal e o Pacto de São José da Costa Rica. São Paulo: Atlas, 2014, p. 192-193.

${ }^{15}$ Ibid., p. 193.

${ }^{16} \mathrm{O}$ nemo tenetur se detegere pode ser considerado um princípio-garantia, segundo a classificação proposta por J. J. Gomes Canotilho, pois pretende "instituir directa e imediatamente uma 'garantia' dos cidadãos" (CANOTIlHO, J. J. Gomes. Direito constitucional e teoria da Constituição. 7. ed. Coimbra: Almedina, 2003, p. 1167).
} 
Revista Eletrônica de Direito Processual - REDP.

Rio de Janeiro. Ano 10. Volume 17. Número 2. Julho a Dezembro de 2016

Periódico Semestral da Pós-Graduação Stricto Sensu em Direito Processual da UERJ

Patrono: José Carlos Barbosa Moreira. ISSN 1982-7636. pp. 377-405

wWw.redp.uerj.br

são "imanentes, implícitos e decorrem da necessidade de coexistência com outros valores que, igualmente, são protegidos pelo ordenamento, em sede constitucional”. Esses outros valores, que podem limitar o princípio analisado, são representados pela paz social e pela segurança pública. De qualquer modo, as restrições sempre deverão ser guiadas pelo princípio da proporcionalidade, que exige ser a limitação efetuada mediante promulgação de lei estrita e prévia (com caráter geral e abstrato, com disposições claras e objetivas, inexistindo indeterminações), observado o controle jurisdicional no caso concreto - que, nas hipóteses de intervenções corporais, deve ser prévio - e os três subprincípios da proporcionalidade: a adequação, a necessidade e a proporcionalidade em sentido estrito ${ }^{17}$.

Quanto ao âmbito de proteção, há divergência doutrinária, não entrando os autores em um consenso acerca de quais condutas podem ser exigidas da pessoa sem que haja violação ao nemo tenetur se detegere. Sobre o tema, adverte-se que serão exploradas as diferentes opiniões dos pensadores no que toca, exclusivamente, às investigações corporais em face da garantia contra a autoincriminação, mas destaca-se que a divergência é mais ampla, englobando, por exemplo, a (in)exigibilidade de o imputado dizer a verdade perante as autoridades.

A linha adotada por Maria Elizabeth Queijo é a de que as provas que implicam investigação corporal não invasiva podem ser realizadas sem a anuência da pessoa, desde que a técnica adotada não exija uma colaboração ativa da mesma e, ainda, sendo imprescindível o controle jurisdicional prévio para a verificação dos critérios da proporcionalidade na limitação e na lei que restringe a garantia contra a autoincriminação $^{18}$.

A doutrinadora continua, aduzindo que, tratando-se de intervenção corporal invasiva ou não invasiva que demande comportamento ativo do sujeito, o consentimento deverá ser prévio, expresso, livre e consciente. A autorização judicial, nessas hipóteses, não supre a dita anuência ${ }^{19}$.

\footnotetext{
${ }^{17}$ QUEIJO, Maria Elizabeth. O direito de não produzir prova contra si mesmo: o princípio nemo tenetur se detegere e suas decorrências no processo penal. 2. ed. São Paulo: Saraiva, 2012, p. 406-411.

${ }^{18}$ QUEIJO, Maria Elizabeth. O direito de não produzir prova contra si mesmo: o princípio nemo tenetur se detegere e suas decorrências no processo penal. 2. ed. São Paulo: Saraiva, 2012, p. 413.

${ }^{19}$ Ibid., p. 411-413.
} 
Revista Eletrônica de Direito Processual - REDP.

Rio de Janeiro. Ano 10. Volume 17. Número 2. Julho a Dezembro de 2016

Periódico Semestral da Pós-Graduação Stricto Sensu em Direito Processual da UERJ

Patrono: José Carlos Barbosa Moreira. ISSN 1982-7636. pp. 377-405

www.redp.uerj.br

Renato Brasileiro de Lima, seguindo o posicionamento referido acima, elucida que, sendo a intervenção corporal não invasiva, a prova poderá ser efetuada mesmo sem o consentimento do agente, desde que esse último não precise desempenhar uma colaboração ativa, realizar um facere, uma ação. Todavia, sendo a intervenção corporal invasiva ou intervenção que demande um comportamento ativo, o indivíduo a ser examinado não é obrigado a colaborar, podendo, validamente, recusar-se a confeccionar a prova, não advindo qualquer prejuízo para si em razão dessa atitude negativa ${ }^{20}$.

Wagner Marteleto Filho, por sua vez, entende que o nemo tenetur se detegere pode ser desdobrado em duas esferas: a de princípio e a de regra. O princípio, a priori, "autoriza o acusado a não cooperar com a produção da prova, exercendo a autodefesa negativa"; contudo, poderão ocorrer restrições nesse plano, uma vez que é viável o estabelecimento de uma cooperação passiva ou de uma cooperação inconsciente. Nesse contexto, afirma Wagner Marteleto Filho que as intervenções corporais, pertencendo todas à cooperação passiva, são legítimas, desde que presentes os limites da máxima da proporcionalidade e a lei que regulamente a ação. A regra, de outro viés, outorga ao indivíduo os direitos ao silêncio e a não realização de conduta ativa que introduza informação ao processo. Nesse último plano, não há possibilidade de limitação ${ }^{21}$.

Prosseguindo no seu raciocínio, o referido doutrinador pontua que, no Brasil, não existindo regulamentação legal expressa que autorize, as intervenções corporais, sejam invasivas ou não invasivas, nos moldes trazidos por Queijo, apenas poderão ser realizadas com consentimento válido do sujeito. Dessa forma, inexistindo o dever de colaboração, nenhum prejuízo pode ser atribuído àquele que se recusar a cooperar com a persecução penal. Cabe destacar, outrossim, que Wagner Marteleto Filho diferencia o exame de DNA das intervenções coercitivas, alegando ser aquele um tipo especial de perícia e, por isso, não exigindo previsão legal expressa para a sua imposição ${ }^{22}$.

${ }^{20}$ LIMA, Renato Brasileiro de. Manual de processo penal. 2. ed. rev. atual. ampl. Salvador: Jus Podivm, 2014 , p. 81 e $84-85$.

${ }^{21}$ MARTELETO FILHO, Wagner. $O$ direito à não autoincriminação no processo penal contemporâneo: (investigação genética, interceptações telefônicas e ambientais, agentes infiltrados e outros problemas). Belo Horizonte: Del Rey, 2012, p. 64-66, 86 e 102.

${ }^{22}$ MARTELETO FILHO, Wagner. $O$ direito à não autoincriminação no processo penal contemporâneo: (investigação genética, interceptações telefônicas e ambientais, agentes infiltrados e outros problemas). Belo Horizonte: Del Rey, 2012, p. 159-160. 
Revista Eletrônica de Direito Processual - REDP.

Rio de Janeiro. Ano 10. Volume 17. Número 2. Julho a Dezembro de 2016

Periódico Semestral da Pós-Graduação Stricto Sensu em Direito Processual da UERJ

Patrono: José Carlos Barbosa Moreira. ISSN 1982-7636. pp. 377-405

www.redp.uerj.br

Rodrigo Vaz Silva, estudando a incidência do nemo tenetur se detegere na extração de material genético de modo coercitivo com a finalidade de confecção de exame de DNA, aduz que a garantia contra a autoincriminação pode ser restringida, desde que respeitados os ditames decorrentes do Estado Democrático de Direito. Diz o autor que a garantia em tela é um mandamento de otimização, protegendo, prima facie, o imputado das situações em que precisa cooperar na persecução penal. Havendo outros valores constitucionais de igual importância, pode ser imposta restrição ao princípio do nemo tenetur se detegere, sendo que tal limitação deverá ocorrer, necessariamente, por meio de lei em sentido estrito, a qual deverá estabelecer as situações de obrigatoriedade, as finalidades do ato coercitivo e as consequências para a pessoa que se negar a cooperar. Quanto ao tipo de colaboração ativa ou passiva - que pode ser exigida do sujeito, pontua o pensador que não há um critério determinante que mostre uma "melhor opção", sustentando que há a possibilidade de permitir apenas a cooperação passiva, assim como ambas as colaborações ${ }^{23}$.

Já o magistério de Eugênio Pacelli de Oliveira é no sentido de que a garantia contra a autoincriminação engloba a possibilidade de o imputado permanecer em silêncio, bem como o impedimento de que ele seja compelido a produzir ou a contribuir com a formação de prova contrária ao seu interesse. Esse último caso, destaca o autor, somente poderá ser limitado em situações excepcionalíssimas, sendo essencial a previsão expressa em lei e a ausência de risco de afetação aos direitos e garantias fundamentais da pessoa ${ }^{24}$.

No que diz respeito às intervenções corporais, Eugênio Pacelli de Oliveira grifa que é indispensável aplicar o nemo tenetur se detegere nos limites de sua finalidade: proteção à dignidade humana, à integridade física e mental da pessoa, à capacidade de autodeterminação desta e ao direito de não ser obrigado a depor contra si. Assim, o doutrinador pontua que nada impedirá que as ingerências humanas ${ }^{25}$ sejam efetuadas se:

\footnotetext{
23 SILVA, Rodrigo Vaz. Princípio da legalidade, direitos fundamentais e máxima da proporcionalidade: análise da obrigatoriedade de submissão ao exame de DNA no ordenamento jurídico-penal brasileiro. 2013. 175 f. Dissertação (Mestrado em Ciências Criminais) - Faculdade de Direito, Pontifícia Universidade Católica do Rio Grande do Sul, Porto Alegre, 2013, p. 122-123.

${ }^{24}$ OLIVEIRA, Eugênio Pacelli de. Curso de processo penal. 17. ed. São Paulo: Atlas, 2013, p. 41.

${ }_{25}$ As intervenções corporais, ou seja, os atos de investigação ou de obtenção de prova sobre o corpo do próprio acusado, também podem ser denominadas investigações corporais ou ingerências humanas (FIORI, Ariane Trevisan. Os direitos individuais e a intervenção corporal: a necessária releitura constitucional como forma de efetivação dos direitos fundamentais. In: CONGRESSO NACIONAL MANAUS, 15., 2006, Manaus. Anais... Manaus: CONPEDI/UEA, $2006 . \quad$ Disponível em: <http://www.conpedi.org.br/manaus/arquivos/anais/manaus/hermeneutica_ariane trevisan_fiori.pdf $>$.
} 
Revista Eletrônica de Direito Processual - REDP.

Rio de Janeiro. Ano 10. Volume 17. Número 2. Julho a Dezembro de 2016

Periódico Semestral da Pós-Graduação Stricto Sensu em Direito Processual da UERJ

Patrono: José Carlos Barbosa Moreira. ISSN 1982-7636. pp. 377-405

wWw.redp.uerj.br

existir previsão expressa em lei; o exame pericial seja efetivamente necessário para a comprovação da infração penal (pela complexidade do crime ou pela impossibilidade prática de obtenção de outras provas); e houver controle judicial, o qual poderá ser feito posteriormente, quando existir urgência inadiável ${ }^{26}$.

Quando houver recusa do imputado à realização das alegadas intervenções, Eugênio Pacelli de Oliveira advoga pela possibilidade de aplicação analógica, no processo penal, do artigo 232 do Código Civil (“A recusa à perícia médica ordenada pelo juiz poderá suprir a prova que se pretendia obter com o exame"). Declara que, havendo um conjunto probatório mínimo, mas insuficiente, a recusa injustificada pode ser usada para o convencimento do juiz, o qual se baseará em presunção legal ${ }^{27}$.

Para encerrar, tem-se o posicionamento de Aury Lopes Jr., Nereu José Giacomolli e André Nicolitt, que, diversamente dos demais, defendem a impossibilidade de executar qualquer tipo de intervenção corporal sem o expresso consentimento do sujeito passivo.

Aury Lopes Jr., no livro Sistemas de Investigação Preliminar no Processo Penal, ao tratar das intervenções corporais coercitivas, pontua claramente que não concorda, em hipótese alguma, com a extração compulsória de material genético, tendo em vista ser impossível restringir a garantia de não fazer prova contra si mesmo tão somente em favor de uma proporcionalidade entre a prova obtida e o sofrimento/constrangimento infligido ao sujeito passivo da medida ${ }^{28}$ :

O autor assevera que o direito de defesa, sob o ponto de vista negativo, não pode ser limitado, principalmente porque, no processo penal, a carga probatória recai exclusivamente sobre a acusação, não podendo ser o sujeito passivo compelido a auxiliá-la. Frisa que há inúmeros outros direitos fundamentais que são violados no momento em que se autoriza uma intervenção corporal coercitiva: o direito à vida; a proibição da tortura e de tratamento desumano ou degradante; o direito à intimidade, à vida privada, à honra e à

Acesso em: 09 mar. 2015; HERNÁNDEZ, Àngel Gil. Intervenciones corporales y derechos fundamentales, p. 37, apud QUEIJO, Maria Elizabeth. $O$ direito de não produzir prova contra si mesmo: o princípio nemo tenetur se detegere e suas decorrências no processo penal. 2. ed. São Paulo: Saraiva, 2012, p. 289-290).

${ }^{26}$ OLIVEIRA, Eugênio Pacelli de. Curso de processo penal. 17. ed. São Paulo: Atlas, 2013, p. 389.

${ }^{27}$ Ibid., p. 400-401.

${ }^{28}$ LOPES JR., Aury. Sistemas de investigação preliminar no processo penal. 3. ed. rev. ampl. atual. Rio de Janeiro: Lumen Juris, 2005, p. 359. 
Revista Eletrônica de Direito Processual - REDP.

Rio de Janeiro. Ano 10. Volume 17. Número 2. Julho a Dezembro de 2016

Periódico Semestral da Pós-Graduação Stricto Sensu em Direito Processual da UERJ

Patrono: José Carlos Barbosa Moreira. ISSN 1982-7636. pp. 377-405

www.redp.uerj.br

imagem das pessoas. De qualquer modo, destaca que submeter um indivíduo a tais medidas equivale a autorizar a tortura para o alcance da confissão no interrogatório ${ }^{29}$.

Nada impede, por outro lado, conforme o doutrinador, que, havendo recusa, o material genético do sujeito passivo seja colhido pela via da busca e apreensão de roupas, travesseiros, escova de cabelo, entre outros objetos encontrados na residência dele ${ }^{30}$.

De outra banda, na hipótese de o princípio da proporcionalidade ser acolhido, autorizando-se as medidas de intervenção corporal, Aury Lopes Jr., adequando sua linha de pensamento, esclarece que certas ingerências humanas poderiam ser efetuadas mesmo sem a concordância do indivíduo. Essas intervenções seriam aquelas em que a obtenção das células necessárias para a confecção do exame ocorresse de forma absolutamente indolor e inofensiva, não causando, ainda, nenhum risco à saúde, integridade física ou mental do sujeito passivo. Todavia, mesmo para essa situação de admissão da coerção, é essencial a existência de norma processual prévia, estabelecendo os casos e a forma como deverá ser realizada a ingerência, e de autorização por meio de decisão judicial fundamentada e passível de recurso. Esta decisão, além de outros requisitos para determinar a extração forçada, deverá levar em consideração a gravidade do fato e a impossibilidade de comprovar a autoria - ou algum pressuposto de responsabilidade ${ }^{31}$.

Ponderando sobre a abrangência do nemo tenetur se detegere, Nereu José Giacomolli afirma que a "colaboração" do imputado na produção probatória, quando não for voluntária, viola, ademais da garantia em evidência, o estado de inocência e a ampla defesa, não importando, para tanto, qual o tipo de cooperação: se ativa ou passiva, se invasiva ou não, se declaratória ou comportamental. O autor destaca que, apesar de outros pensadores diferenciarem entre conduta ativa e passiva, entre interferência invasiva interna e externa, entre intervenção dolorosa e não dolorosa, entre outras distinções, sua posição é no sentido de que "essa separação, na perspectiva do pensamento linear, [é] incompatível com a complexidade situacional e do pensamento problemático e complexo da contemporaneidade". Assim, assevera que, em qualquer dessas situações elencadas, há

\footnotetext{
${ }^{29}$ LOPES JR., Aury. Sistemas de investigação preliminar no processo penal. 3. ed. rev. ampl. atual. Rio de Janeiro: Lumen Juris, 2005, p. 356-357.

${ }^{30}$ LOPES JR., Aury. Direito processual penal. 10. ed. São Paulo: Saraiva, 2013, p. 630.

${ }^{31}$ LOPES JR., op. cit., p. 359-361 e 364-365.
} 
Revista Eletrônica de Direito Processual - REDP.

Rio de Janeiro. Ano 10. Volume 17. Número 2. Julho a Dezembro de 2016

Periódico Semestral da Pós-Graduação Stricto Sensu em Direito Processual da UERJ

Patrono: José Carlos Barbosa Moreira. ISSN 1982-7636. pp. 377-405

www.redp.uerj.br

uma objetivação do sujeito passivo, deixando este de ser um sujeito de direitos e garantias dentro do processo $^{32}$.

Além disso, o autor esclarece que a garantia contra a autoincriminação não é absoluta, podendo ser limitada por uma lei adequada à convencionalidade e à constitucionalidade, mediante reserva jurisdicional. Essa lei não poderá eliminar ou afetar o conteúdo essencial da garantia fundamental em questão. Esse controle legal e essa avaliação judicial, ainda, deverão observar ou o critério da proporcionalidade (necessidade, adequação e proporcionalidade em sentido estrito) ou o da razoabilidade (compatibilidade entre meios e fins). A metodologia utilizada na confecção da prova também deverá respeitar alguns parâmetros: ser lícita e satisfatória às exigências legais e convencionais ${ }^{33}$.

Nereu José Giacomolli conclui alertando que observar os ditames da garantia fundamental a não autoincriminação não acarreta na impossibilidade de produzir a prova desejada, uma vez que há outros meios para a demonstração da autoria, da materialidade e para alcançar o convencimento do juiz no que tange à responsabilidade criminal do imputado, tais como: coleta de saliva em copos, de xícaras utilizadas pelo sujeito passivo e de filtro de cigarros ${ }^{34}$.

Por fim, André Nicolitt, sobre a colheita de material biológico através de intervenção corporal, estabelece que, não havendo o consentimento do sujeito submetido ao exame, tanto as investigações corporais invasivas quanto as não invasivas estariam proscritas, tendo em vista a garantia contra a autoincriminação e o princípio da dignidade humana. No que concerne às não invasivas, alega o autor que, não havendo anuência, será necessário o emprego de força sobre o corpo da pessoa, a fim de vencer a resistência da mesma, o que equivale à tortura ${ }^{35}$.

Destarte, após essa breve passagem pela doutrina nacional que trata do tema proposto, percebe-se que: há autores que acreditam que o núcleo essencial da garantia contra a autoincriminação engloba a impossibilidade de cooperação ativa por parte do sujeito passivo, bem como de intervenção invasiva nele; outros entendem que o núcleo

\footnotetext{
${ }^{32}$ GIACOMOLLI, Nereu José. O devido processo penal: abordagem conforme a Constituição Federal e o Pacto de São José da Costa Rica. São Paulo: Atlas, 2014, p. 193-195.

${ }^{33}$ Ibid., p. 194-195.

${ }^{34}$ Ibid., p. 196.

35 NICOLITT, André. Banco de dados de perfis genéticos (DNA): as inconstitucionalidades da Lei 12.654/2012. Boletim IBCCRIM, São Paulo, ano 21, n. 245, p. 15, abr. 2013.
} 
Revista Eletrônica de Direito Processual - REDP.

Rio de Janeiro. Ano 10. Volume 17. Número 2. Julho a Dezembro de 2016

Periódico Semestral da Pós-Graduação Stricto Sensu em Direito Processual da UERJ

Patrono: José Carlos Barbosa Moreira. ISSN 1982-7636. pp. 377-405

www.redp.uerj.br

essencial é mais elástico e que, não havendo consentimento, a prova deverá ser buscada de outra forma, pois não é possível efetuar intervenção corporal sem a anuência do sujeito passivo; e outros que afirmam existir a possibilidade de restrição ao nemo tenetur se detegere, desde que respeitados os princípios da legalidade e da proporcionalidade.

Possibilitada a visualização da falta de harmonia, nota-se o quão difícil afirmar, com certeza, se certa conduta viola o nemo tenetur se detegere. Nesse momento, então, cabe analisar a Lei n. $.^{\circ} 12.654 / 2012$, seus problemas formais e materiais, e entender o porquê, embora haja divergência, sustenta-se que o diploma legal em questão, sem sombra de dúvidas, viola a garantia evidenciada.

\section{A IDENTIFICAÇÃO CRIMINAL BASEAdA NA EXTRAÇÃO DE PERFIL GENÉTICO DOS INVESTIGADOS E DOS ACUSADOS: OFENSA À GARANTIA CONTRA A AUTOINCRIMINAÇÃO?}

A Lei n. ${ }^{\circ}$ 12.654/2012, em uma de suas modificações ao ordenamento jurídico, trouxe a identificação criminal por perfil genético. Essa identificação criminal, conforme o novo diploma, pode ocorrer em dois momentos diversos: na fase pré-processual ou processual, alcançando as pessoas suspeitas e as acusadas; e na fase executória da pena, envolvendo as pessoas condenadas por crime praticado, dolosamente, com violência de natureza grave contra pessoa ou por delito considerado hediondo.

No que tange à identificação criminal genética de investigados e de suspeitos, como já referido anteriormente, não é uníssono na doutrina brasileira que a Lei n. ${ }^{\circ}$ 12.654/2012 afronte a garantia fundamental a não produzir prova contra si mesmo. Torna-se interessante, então, um exame dos argumentos de alguns autores, a fim de perceber a razão da divergência.

Eugênio Pacelli de Oliveira, ao escrever sobre o tema, grifa que a identificação criminal genética dos suspeitos/acusados não deve ser invalidada pelo nemo tenetur se detegere, porquanto o que pode ser violado com a medida são direitos materiais da pessoa (integridade física e/ou psíquica, por exemplo) e não a garantia aludida. Pontua que a violação aos mencionados direitos materiais ocorrerá dependendo do tipo de exame empregado, da existência de prescindibilidade da intervenção e da não observância de 
Revista Eletrônica de Direito Processual - REDP.

Rio de Janeiro. Ano 10. Volume 17. Número 2. Julho a Dezembro de 2016

Periódico Semestral da Pós-Graduação Stricto Sensu em Direito Processual da UERJ

Patrono: José Carlos Barbosa Moreira. ISSN 1982-7636. pp. 377-405

wWw.redp.uerj.br

meios de coleta não abusivos e desnecessários. Destaca também que, se mantida a excepcionalidade da insurgência, controlada judicialmente por decisão fundamentada, nada há de inconstitucional na Lei n. ${ }^{\circ} 12.654 / 2012^{36}$.

Maria Elizabeth Queijo, divergindo do doutrinador supracitado, compreende que a Lei n. ${ }^{\circ}$ 12.654/2012 deve ser declarada inconstitucional em decorrência da garantia contra a autoincriminação. Esclarece que, diferentemente do que consta no diploma legal, a finalidade da coleta de material biológico não é a de mera identificação criminal, mas sim de comprovação da autoria ou da participação da pessoa em algum delito, seja em persecução penal futura ou em andamento; portanto, o objetivo é probatório. Desse modo, frisa que é notória a possibilidade de incidência do nemo tenetur se detegere na perícia feita com o material biológico do identificado, inexistindo dever de colaboração desse último, tampouco consequências pela recusa a se submeter ao ato ${ }^{37}$.

Recordando os critérios para que o nemo tenetur se detegere seja limitado, Maria Elizabeth Queijo elucida que a Lei n. ${ }^{\circ} 12.654 / 2012$ não se presta a tal fim, pois, embora determine a autorização da coleta do material por decisão judicial fundamentada, "não propõe critérios pautados na proporcionalidade a nortear a decisão judicial, conferindo amplitude excessiva à coleta de material genético para fins criminais". Lembra que um dos únicos requisitos autorizadores da intervenção corporal em tela é que ela seja "essencial às investigações policiais", porém inexiste qualquer parâmetro para definir o que é essa essencialidade ${ }^{38}$.

Igualmente, Aury Lopes Jr. posiciona-se contrariamente à novatio legis, visto que ela fere gravemente a garantia constitucional de não produzir prova contra si mesmo, além de violar os direitos à privacidade, à integridade física e à dignidade da pessoa humana. Contudo, estando a lei em plena vigência, o autor aponta detalhes importantes que devem ser observados, a fim de não tornar a intervenção estudada algo banal, tentando-se amenizar as violações aos direitos e garantias fundamentais mencionados. Utiliza como base os requisitos autorizadores da ingerência, esclarecendo os cuidados que devem ser

\footnotetext{
${ }^{36}$ OLIVEIRA, Eugênio Pacelli de. Curso de processo penal. 17. ed. São Paulo: Atlas, 2013, p. 396-397.

37 QUEIJO, Maria Elizabeth. O princípio nemo tenetur se detegere e a coleta de material genético: identificação criminal ou colaboração na produção da prova? Boletim IBCCRIM, São Paulo, ano 21, n. 250, p. 8, set. 2013.

${ }^{38}$ Ibid., p. 9.
} 
Revista Eletrônica de Direito Processual - REDP.

Rio de Janeiro. Ano 10. Volume 17. Número 2. Julho a Dezembro de 2016

Periódico Semestral da Pós-Graduação Stricto Sensu em Direito Processual da UERJ

Patrono: José Carlos Barbosa Moreira. ISSN 1982-7636. pp. 377-405

www.redp.uerj.br

tomados. Primeiro, em relação à "necessidade para as investigações", o autor afirma que tal redação é genérica, subordinando o ato apenas ao interesse da autoridade policial, mas, independentemente disso, o pedido para a efetivação da intervenção corporal deve ser fundamentado e deixar claro, no caso concreto, a imprescindibilidade da medida; ou seja, para que seja aplicada a identificação genética - ultima ratio do sistema -, não deve existir outro modo de comprovação da autoria delitiva; caso contrário, "basta uma boa retórica policial e uma dose de decisionismo judicial para que os abusos ocorram”. Segundo, no que concerne à "autorização judicial", diz o doutrinador que a decisão do magistrado precisará ser fundamentada na real necessidade da ingerência humana e na impossibilidade de se obter a prova da autoria criminosa por meio menos lesivo e gravoso para o sujeito passivo $^{39}$.

Nereu José Giacomolli, seguindo a linha dos autores acima elencados, declara que, se considerada constitucional, a Lei n. ${ }^{\circ}$ 12.654/2012 sepultará a garantia constitucional de não produzir prova contra si mesmo, uma vez que autoriza a extração coativa do material biológico do sujeito passivo. $\mathrm{O}$ autor refere que, sendo a redação genérica e irrestrita, o novo diploma legal relativizou e agrediu a garantia mencionada de forma sub-reptícia, tornando-se também incompatível com o devido processo e com a dignidade da pessoa humana. Nesse sentido, afirma que devem preponderar os diplomas internacionais que tratam da matéria em detrimento da legislação pátria, "como a Declaração Internacional sobre os Dados Genéticos Humanos da UNESCO, de 2004, onde o consentimento do sujeito prevalece" 40 .

A Declaração Internacional sobre os Dados Genéticos Humanos da UNESCO traz a importância do consentimento no seu artigo $8^{\circ}$, “a”. Esse dispositivo estabelece que é imprescindível a obtenção de consentimento prévio, livre, informado e expresso para o recolhimento e posterior tratamento, utilização ou conservação de qualquer informação genética, seja o procedimento invasivo ou não.

Nota-se o quão essencial é o consentimento daquele que será submetido à extração de informação genética. Para a Declaração, não há que se falar em possibilidade de

\footnotetext{
${ }^{39}$ LOPES JR., Aury. Direito processual penal. 10. ed. São Paulo: Saraiva, 2013, p. 633-635.

${ }^{40}$ GIACOMOLLI, Nereu José. $O$ devido processo penal: abordagem conforme a Constituição Federal e o Pacto de São José da Costa Rica. São Paulo: Atlas, 2014, p. 200-201.
} 
Revista Eletrônica de Direito Processual - REDP.

Rio de Janeiro. Ano 10. Volume 17. Número 2. Julho a Dezembro de 2016

Periódico Semestral da Pós-Graduação Stricto Sensu em Direito Processual da UERJ

Patrono: José Carlos Barbosa Moreira. ISSN 1982-7636. pp. 377-405

www.redp.uerj.br

qualquer procedimento, se o sujeito passivo não o autorizar, exatamente porque esse sujeito tem, a seu favor, a garantia contra a autoincriminação. É nessa questão que a legislação brasileira falha, porquanto não deixa expresso que os procedimentos para extração de material biológico não podem ser realizados de modo coercitivo.

Giancarlo Silkunas Vay e Pedro José Rocha e Silva, ao escreverem sobre o assunto, reforçam justamente a impossibilidade da coleta do material biológico ser coercitiva, ou seja, a impossibilidade de aplicação da medida quando ausente o consentimento do sujeito passivo. Os autores sustentam seu entendimento na lógica estrutural do processo penal brasileiro, visto através da Constituição Federal de 1988. Assim, sabendo-se que a Carta Magna traz um modelo processual penal de cunho acusatório, os papeis das partes da relação processual estão bem delineados: o juiz como ser imparcial, pois inerte e afastado da produção das provas; o órgão acusador como o interessado na confecção de um conjunto probatório que comprove a acusação que está sendo feita; e a defesa como aquela que somente pratica atos de resistência à pretensão acusatória, não possuindo qualquer ônus probatório em razão da presunção de inocência. Diante disso, pontuam que o nemo tenetur se detegere restaria violado, se a coleta de material biológico de modo coercitivo for devidamente utilizada, posto que se estaria exigindo do sujeito passivo um comportamento diverso daquele referente a sua posição no processo, que é o de resistência ${ }^{41}$.

De outra banda, com um posicionamento sui generis, há Wagner Marteleto Filho, desacreditado de que a Lei n. ${ }^{\circ}$ 12.654/2012 tenha tentado instituir no ordenamento pátrio as intervenções corporais coercitivas e, mesmo que tivesse, vislumbra não estar apta a essa finalidade. $\mathrm{O}$ autor justifica seu posicionamento com duas constatações: a) o diploma legal não faz nenhuma referência ao emprego de coerção física sobre o sujeito passivo, quando esse se recusar a participar da coleta de seu material biológico para a obtenção do perfil genético, tampouco disciplinou o procedimento a ser seguido, caso tal circunstância ocorra; e b) não há previsão expressa na nova Lei acerca da possibilidade de extração do material biológico do indiciado, tendo referido tão somente a possibilidade de coleta desse

${ }^{41}$ VAY, Giancarlo Silkunas; SILVA, Pedro José Rocha e. A identificação criminal mediante coleta de material biológico que implique intervenção corporal e o princípio do nemo tenetur se detegere. Boletim IBCCRIM, São Paulo, ano 20, n. 239, p. 13, out. 2012. 
Revista Eletrônica de Direito Processual - REDP.

Rio de Janeiro. Ano 10. Volume 17. Número 2. Julho a Dezembro de 2016

Periódico Semestral da Pós-Graduação Stricto Sensu em Direito Processual da UERJ

Patrono: José Carlos Barbosa Moreira. ISSN 1982-7636. pp. 377-405

www.redp.uerj.br

material, o que é diferente de extraí-lo. Essa coleta mencionada, inclusive, poderá ser feita sem a existência de intervenção corporal, quando o material for disponibilizado voluntariamente pelo imputado ou descartado por ele em qualquer local. O autor, ainda, opina que, diante de sua redação, a nova Lei não autorizou a intervenção corporal para a obtenção de perfil genético no que toca ao acusado no curso de ação penal, com o escopo de realizar exame de $\mathrm{DNA}^{42}$.

Ainda, em relação ao aspecto formal da Lei n. ${ }^{\circ}$ 12.654/2012, Wagner Marteleto Filho entende que ela não é idônea a disciplinar um meio de prova complexo, intenso e de alcance tão amplo como o das intervenções corporais coercitivas, o qual demanda regulamentação legal específica e detalhada mediante norma processual penal. O princípio da legalidade, conclui, continua sendo um obstáculo insuperável, mas não o nemo tenetur se detegere, que admite limitação ${ }^{43}$.

Diante disso, percebe-se que há, no mínimo, três posições diferentes no que toca à violação ou não da garantia constitucional contra a autoincriminação pela Lei n. $^{\text {o }}$ 12.654/2012; veja-se: 1) há os autores que entendem que há a violação do nemo tenetur se detegere pelo novo diploma legal, uma vez que a medida ali elencada, de coleta de material biológico, ultrapassa a mera identificação criminal, entrando na seara probatória, devendo existir, então, o consentimento do identificado; 2) há aqueles que sustentam que somente direitos materiais serão desrespeitados pela Lei examinada, não havendo que se falar em violação à garantia; e 3) alguns autores compreendem a possibilidade de limitação da garantia fundamental a não autoincriminação, desde que por lei processual penal detalhada, o que não é o caso da Lei n. ${ }^{\circ}$ 12.654/2012, esbarrando o sistema jurídico na adequada regulamentação da matéria.

Pois bem, acredita-se que a Lei n. ${ }^{\circ}$ 12.654/2012 violou, sim, o nemo tenetur se detegere, autorizando que o indivíduo seja obrigado a criar prova contra si mesmo, uma vez que o material biológico coletado será utilizado com a finalidade probatória, na tentativa de identificar a autoria delitiva. Corrobora essa tese o fato de que, havendo

\footnotetext{
${ }^{42}$ MARTELETO FILHO, Wagner. O direito à não autoincriminação no processo penal contemporâneo: (investigação genética, interceptações telefônicas e ambientais, agentes infiltrados e outros problemas). Belo Horizonte: Del Rey, 2012, p. 161-162.

${ }^{43}$ MARTELETO FILHO, Wagner. O direito à não autoincriminação no processo penal contemporâneo: (investigação genética, interceptações telefônicas e ambientais, agentes infiltrados e outros problemas). Belo Horizonte: Del Rey, 2012, p. 162-163.
} 
Revista Eletrônica de Direito Processual - REDP.

Rio de Janeiro. Ano 10. Volume 17. Número 2. Julho a Dezembro de 2016

Periódico Semestral da Pós-Graduação Stricto Sensu em Direito Processual da UERJ

Patrono: José Carlos Barbosa Moreira. ISSN 1982-7636. pp. 377-405

www.redp.uerj.br

coincidência de perfis genéticos entre aquele encontrado na vítima ou no local do crime com aquele coletado do sujeito passivo, as informações obtidas deverão constar em laudo pericial firmado por perito oficial devidamente habilitado (artigo $5^{\circ}$-A, parágrafo $3^{\circ}$, da Lei n. $\left.{ }^{\circ} 12.037 / 2009\right)$, isto é, será feita perícia.

Logo, classificando a coleta tratada pela Lei n. ${ }^{\circ}$ 12.654/2012 como meio probatório, pelo menos aquela realizada na pessoa do investigado e do acusado, é inequívoco que a garantia fundamental de não produzir prova contra si mesmo é aplicável, independentemente se a técnica a ser utilizada é invasiva ou não. O consentimento daquele a ser identificado, consequentemente, é imprescindível à validade da medida.

Mesmo que se cogitasse a não violação material à garantia contra a autoincriminação, a novatio legis não é, formalmente, uma lei processual penal apta a limitar o nemo tenetur se detegere por ser extremamente vaga em diversos aspectos, como, por exemplo, ao não definir o que é "essencial às investigações policiais", critério autorizador da coleta de material biológico na seara pré-processual e processual, e também por não determinar a observância da proporcionalidade, tanto no pedido de autorização quanto na própria decisão judicial. Essas falhas do diploma inovador o impedem de restringir uma garantia constitucional, que, embora não absoluta, deve prevalecer sobre uma lei limitadora indeterminada.

Cabe destacar que a máxima da proporcionalidade, tratando de restrição a direito ou garantia fundamental, é extremamente importante, pois é fundamento para a legitimidade da lei que pretende operar a restrição e é preceito a ser observado nas decisões judiciais que tratam da matéria. In casu, a proporcionalidade ganha grande força, porquanto, embora se reconheça que a Lei . $^{\circ}$ 12.654/2012 deva ser entendida como inconstitucional por afrontar ao nemo tenetur se detegere, o diploma está em vigor, não havendo posicionamento do Supremo Tribunal Federal a respeito. A mencionada máxima não foi observada quando da redação da Lei estudada e, por isso, torna-se vital a sua observância em sede de aplicação do texto normativo, buscando-se amenizar os males criados.

Analisados os argumentos doutrinários acerca da validade da Lei n. ${ }^{\circ}$ 12.654/2012 frente à garantia contra a autoincriminação e apresentada a conclusão, no sentido da inaplicabilidade de tal diploma legal como limitação à essa última, prevalecendo a necessidade do consentimento do sujeito passivo, pensa-se que é oportuno um breve olhar 
Revista Eletrônica de Direito Processual - REDP.

Rio de Janeiro. Ano 10. Volume 17. Número 2. Julho a Dezembro de 2016

Periódico Semestral da Pós-Graduação Stricto Sensu em Direito Processual da UERJ

Patrono: José Carlos Barbosa Moreira. ISSN 1982-7636. pp. 377-405

www.redp.uerj.br

no tema das provas genéticas e sua confiabilidade na resolução de causas criminais. A prova genética é, em verdade, a prova pericial produzida a partir da coleta do DNA do imputado, quando há coincidência entre as moléculas (o DNA encontrado e o DNA extraído). O tema proposto é de grande valia, especialmente porque é imprescindível desmistificar a prova científica baseada nos perfis genéticos, que é entendida como algo infalível.

\section{A VAloração da prova genética no PROCESSO PENAL E A QUESTÃO DA CONFIABILIDADE NO EXAME DE DNA}

No atual processo penal brasileiro, as provas confeccionadas para uma determinada ação judicial devem ser avaliadas, na decisão final, através do sistema denominado de livre convencimento motivado, mas nem sempre isso ocorreu, porquanto outros sistemas já vigoraram com mais ênfase no ordenamento pátrio. $\mathrm{Na}$ verdade, a distinção entre esses modelos de avaliação é a atribuição de maior ou menor subjetividade às decisões, possibilitando que o julgador tenha mais liberdade para avaliar o conjunto probatório, ou não.

Com efeito, o primeiro grande sistema de apreciação das provas foi o chamado "da prova legal”, "da certeza moral do legislador", "da verdade legal”, "da verdade formal” ou "tarifado". Nesse caso, não havia margem de discricionariedade dada ao julgador, autorizando-o a oferecer maior ou menor importância à determinada prova. O julgador deveria seguir, obrigatoriamente, as regras preestabelecidas em lei, sendo que essa última atribuía, de antemão, o valor de cada prova ${ }^{44}$.

Eugênio Pacelli de Oliveira, tratando do tema, escreve que tal modelo de valoração surgiu para superar o excesso de poderes que o juiz tinha nas mãos. Reduziu-se esses poderes por meio de um modelo rígido de apreciação da prova: havia certos meios de prova que deviam ser confeccionados para determinados crimes e, igualmente, havia um valor, fixo e imutável, dado a cada prova, que era pré-definido pelo legislador ${ }^{45}$.

\footnotetext{
${ }^{44}$ CAPEZ, Fernando. Curso de processo penal. 21. ed. São Paulo: Saraiva, 2014, p. 407.

${ }^{45}$ OLIVEIRA, Eugênio Pacelli de. Curso de processo penal. 12. ed. Rio de Janeiro: Lumen Juris, 2009, p. 327-328.
} 
Revista Eletrônica de Direito Processual - REDP.

Rio de Janeiro. Ano 10. Volume 17. Número 2. Julho a Dezembro de 2016

Periódico Semestral da Pós-Graduação Stricto Sensu em Direito Processual da UERJ

Patrono: José Carlos Barbosa Moreira. ISSN 1982-7636. pp. 377-405

www.redp.uerj.br

$\mathrm{O}$ autor supramencionado, ainda, comenta que, tendo em vista que era necessário atingir um patamar mínimo de pontos para que a condenação existisse, caso esse número não fosse alcançado, era viável utilizar a tortura para a obtenção da confissão, já que essa era considerada prova plena ${ }^{46}$.

De outro lado, há o segundo grande sistema de valoração das provas, que é o chamado sistema "da certeza moral do juiz" ou "da íntima convicção". Está-se, aqui, diante do oposto do sistema anterior, haja vista que o magistrado não precisa seguir nenhum critério para efetuar o julgamento, visto que a lei lhe concede ilimitada liberdade para decidir. Não há, portanto, uma ideia de pesos e valores que deve ser obedecida ${ }^{47}$.

Aury Lopes Jr. grifa que, com esse modelo de valoração, acabou-se caindo em outra extremidade, porquanto o julgador acabou por ter liberdade total para valorar a prova, sequer precisando fundamentar a sua decisão. Passou a imperar, então, a discricionariedade e liberdade de julgamento, não havendo a necessidade de demonstração dos elementos que amparavam e legitimavam a decisão final ${ }^{48}$.

Por último, há o terceiro relevante sistema: o "da livre convicção", "da verdade real", "do livre convencimento", "da persuasão racional"49 ou "do livre convencimento

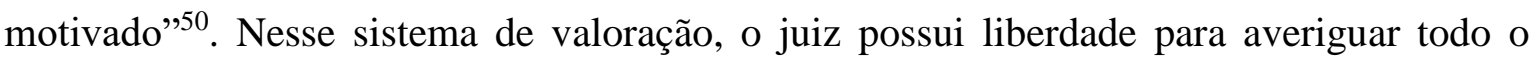
conjunto probatório, formando, assim, a sua convicção. Essa liberdade, entretanto, não é irrestrita, uma vez que é imprescindível que o magistrado motive as suas decisões, sempre dentro de certos limites flexíveis impostos pela lei ${ }^{51}$.

Como dito inicialmente, esse último sistema é o adotado pelo Código de Processo Penal pátrio, nos termos da redação do artigo 155 do referido diploma: "O juiz formará sua convicção pela livre apreciação da prova produzida em contraditório judicial, não podendo fundamentar sua decisão exclusivamente nos elementos informativos colhidos na investigação, ressalvadas as provas cautelares, não repetíveis e antecipadas".

Eugênio Pacelli de Oliveira destaca que, nesse último modelo, o juiz pode fundamentar toda a sua decisão em um único testemunho, desde que em consonância com

\footnotetext{
${ }^{46}$ Ibid., p. 328.

${ }^{47}$ CAPEZ, op.cit., p. 407-408.

${ }^{48}$ LOPES JR., Aury. Direito processual penal. 10. ed. São Paulo: Saraiva, 2013, p. 561.

${ }^{49}$ CAPEZ, Fernando. Curso de processo penal. 21. ed. São Paulo: Saraiva, 2014, p. 408.

${ }^{50}$ LOPES JR., Aury. Direito processual penal. 10. ed. São Paulo: Saraiva, 2013, p. 562.

${ }^{51}$ CAPEZ, op. cit., p. 408.
} 
Revista Eletrônica de Direito Processual - REDP.

Rio de Janeiro. Ano 10. Volume 17. Número 2. Julho a Dezembro de 2016

Periódico Semestral da Pós-Graduação Stricto Sensu em Direito Processual da UERJ

Patrono: José Carlos Barbosa Moreira. ISSN 1982-7636. pp. 377-405

www.redp.uerj.br

outras provas, mesmo que ele esteja em sentido contrário de outras declarações. De qualquer modo, frisa que, embora o julgador tenha liberdade para compor o seu convencimento, ele, necessariamente, deverá expor as razões que o levaram a escolher essa ou aquela prova, declinando uma argumentação racional ${ }^{52}$.

Já Aury Lopes Jr. esclarece que a dita liberdade decorre da ausência de submissão do juiz a questões políticas e econômicas e à vontade da maioria, bem como decorre da inexistência de provas absolutas, devendo ser todas vistas como relativas, pois nenhuma possui maior prestígio que a outra ${ }^{53}$.

Dito isso, convém destacar que, embora o exame baseado no DNA seja extremamente útil na resolução de crimes, notadamente por ser uma prova científica e com grande grau de certeza, ele não pode ser considerado como prova absoluta, sendo apenas mais uma prova produzida nos autos. O sistema de valoração probatória vigente não é mais o da prova legal, mas sim o do livre convencimento motivado e, em decorrência disso, é essencial que eventual exame genético esteja corroborado com outras provas.

Inclusive, a fim de reforçar a impossibilidade de utilização do exame de DNA como prova plena, é importante recordar que tal prova é passível de erro, seja porque as amostras não foram coletadas adequadamente, seja porque o perito, ao final do exame, redigiu o laudo de modo equivocado, ao realizar uma leitura inapropriada do material em análise.

O Conselho Nacional de Pesquisa especificou quatro situações geradoras de erro nas conclusões obtidas pelos laboratórios, ou seja, situações que podem levar a falsas semelhanças entre o DNA-prova e o DNA dos envolvidos no caso. A primeira é quando, em qualquer fase do processo, desde a coleta da prova até o momento da redação do relatório final, acontece falha no manuseio e/ou na rotulagem das amostras. A segunda engloba as hipóteses em que há problemas com os reagentes utilizados, os equipamentos, os controles empregados pelo laboratório ou as técnicas - em todas essas oportunidades se pode chegar a testes deficientes ou a resultados ambíguos. A terceira, por sua vez, envolve a contaminação da prova, o que ocorre sempre que um material estranho, principalmente

52 OLIVEIRA, Eugênio Pacelli de. Curso de processo penal. 12. ed. Rio de Janeiro: Lumen Juris, 2009, p. 328.

${ }^{53}$ LOPES JR., op. cit., p. 562-563. 
Revista Eletrônica de Direito Processual - REDP.

Rio de Janeiro. Ano 10. Volume 17. Número 2. Julho a Dezembro de 2016

Periódico Semestral da Pós-Graduação Stricto Sensu em Direito Processual da UERJ

Patrono: José Carlos Barbosa Moreira. ISSN 1982-7636. pp. 377-405

wWw.redp.uerj.br

material humano, é misturado com a amostra de prova ${ }^{54}$. A quarta, por fim, é a situação em que o erro decorre de uma distorção, consciente ou inconsciente, do analista ${ }^{55}$.

Sobre esse assunto, por exemplo, cabe lembrar que uma das técnicas utilizadas para a análise das amostras biológicas, ao efetuar um exame de DNA, é a chamada PCR (polymerase chain reaction ou reação em cadeia da polimerase ${ }^{56}$ ). A PCR é um procedimento laboratorial que tem como escopo copiar milhões de vezes um determinado segmento curto do $\mathrm{DNA}^{57}$, permitindo uma amplificação seletiva, in vitro, de sequências específicas do DNA estudado ${ }^{58}$. No entanto, mesmo sendo muito utilizada, há desvantagens que decorrem da escolha de tal método, sendo que uma delas é a possibilidade de existência de resultados falso-positivos e falso-negativos. Conforme esclarece o Conselho Nacional de Pesquisa, há probabilidade de erro na técnica de PCR em razão de contaminação do DNA, uma vez que essa situação levará, por consequência, à amplificação do DNA errado. Essas contaminações, via de regra, são percebidas, porquanto o material genético contaminante apresenta um padrão fraco, diferindo do padrão dominante; todavia, caso o DNA contaminante esteja em quantidade suficiente, fornecendo um padrão equivalente ao do DNA estudado, ele poderá ser amplificado normalmente e conduzir a um falso-negativo ("uma não combinação poderia ser declarada quando, na verdade, realmente existe a combinação") ou um falso-positivo ("o perfil de uma amostra de prova é falsamente declarado como semelhante ao tipo genético de outra pessoa") ${ }^{59}$.

\footnotetext{
${ }^{54}$ O Conselho Nacional de Pesquisa, ao escrever sobre a contaminação da prova, refere a existência de três tipos de contaminação: a inadvertida (a contaminação ocorre durante o manuseio da amostra pelos investigadores, por pessoas que pertencem ou não ao laboratório, ou, ainda, ocorre pelo próprio ambiente em que a amostra foi coletada); as amostras mistas (a contaminação ocorre em razão da própria natureza das amostras; é o caso dos "esfregaços vaginais pós-coito", ocasião em que o sêmen e os fluidos vaginais se misturam); e a carryover (a contaminação acontece quando produtos de pré-PCR e pós-PCR se misturam). (CONSELHO NACIONAL DE PESQUISA. A avaliação do DNA como prova forense. Tradução e revisão: F. A. Moura Duarte et al. Ribeirão Preto: FUNPEC, 2001. 283 p. Título original: The evaluation of forensic DNA evidence, p. 92-98).

${ }^{55}$ Ibid., p. 93-99.

${ }^{56}$ JOBIM, Luiz Fernando; COSTA, Luíz Renato; SILVA, Moacir da. Identificação humana: identificação médico legal, perícias odontolegais, identificação humana pelo DNA. 2. ed. Campinas: Millennium Editora, 2012, p. 185.

${ }^{57}$ CONSELHO NACIONAL DE PESQUISA, op. cit., p. 80.

${ }^{58}$ JOBIM; COSTA; SILVA, op. cit., p. 185.

${ }^{59}$ CONSELHO NACIONAL DE PESQUISA. A avaliação do DNA como prova forense. Tradução e revisão: F. A. Moura Duarte et al. Ribeirão Preto: FUNPEC, 2001. 283 p. Título original: The evaluation of forensic DNA evidence, p. 82.
} 
Revista Eletrônica de Direito Processual - REDP.

Rio de Janeiro. Ano 10. Volume 17. Número 2. Julho a Dezembro de 2016

Periódico Semestral da Pós-Graduação Stricto Sensu em Direito Processual da UERJ

Patrono: José Carlos Barbosa Moreira. ISSN 1982-7636. pp. 377-405

www.redp.uerj.br

Percebe-se, destarte, que não é possível confiar, acima de qualquer dúvida, no resultado fornecido pelos laboratórios, especialmente quando não se tem conhecimento de como a prova foi manipulada, armazenada ou qual o grau de qualidade dos procedimentos adotados.

Outra problemática é a da interpretação dos resultados. Isto porque, embora nas conclusões de não coincidência entre os perfis genéticos examinados exista um grau de certeza de quase $100 \%$, as conclusões de coincidência podem provocar equívocos. Quando há coincidência, é forçoso realizar um estudo probabilístico na população local, verificando a possibilidade de vários indivíduos possuírem as mesmas frequências fenotípicas. Nesse diapasão, cabe pontuar que, em um exame de DNA que aponte $99 \%$ de certeza, a porcentagem de $1 \%$ pode equivaler a 5.000 indivíduos, se a população for de 500.000, o que não é uma quantidade a ser desconsiderada. Por isso, sendo a perícia de DNA um exame probabilístico, o resultado apontado nunca deve ser tomado isoladamente. O exame de DNA deve ser reafirmado por outras provas, nunca sendo a única base a sustentar uma sentença condenatória ${ }^{60}$.

Aury Lopes Jr., no que concerne ao presente tema, estabelece que, apesar de o discurso científico ser sedutor, não há provas absolutas na sistemática processual penal, o que pode ser vislumbrado na exposição de motivos do Código de Processo Penal. Afirma que a perícia de DNA “demonstra apenas um grau, maior ou menor, de probabilidade de um aspecto do delito, que não se confunde com a prova de toda a complexidade que constitui o fato" e, assim, esclarece que não basta ocorrer a semelhança entre o DNA do acusado e o material genético encontrado na vítima de algum crime, pois isso não significa que o primeiro tenha praticado o crime contra a segunda necessariamente ${ }^{61}$.

De outra banda, não se pode ignorar que, apesar de o exame de DNA não ser algo infalível, há meios de o tornar mais seguro, o que se alcança através da observância a alguns cuidados ou, como aduz Wagner Marteleto Filho, a alguns requisitos objetivos.

\footnotetext{
${ }^{60}$ MARTELETO FILHO, Wagner. O direito à não autoincriminação no processo penal contemporâneo: (investigação genética, interceptações telefônicas e ambientais, agentes infiltrados e outros problemas). Belo Horizonte: Del Rey, 2012, p. 154-155.

${ }^{61}$ LOPES JR., Aury. Direito processual penal. 10. ed. São Paulo: Saraiva, 2013, p. 637-639.
} 
Revista Eletrônica de Direito Processual - REDP.

Rio de Janeiro. Ano 10. Volume 17. Número 2. Julho a Dezembro de 2016

Periódico Semestral da Pós-Graduação Stricto Sensu em Direito Processual da UERJ

Patrono: José Carlos Barbosa Moreira. ISSN 1982-7636. pp. 377-405

www.redp.uerj.br

Estes requisitos envolvem a coleta do material, a confecção do exame, a capacidade técnica do expert, a imparcialidade do órgão responsável pela análise, entre outros ${ }^{62}$.

Por exemplo, quanto à coleta das amostras, Wagner Marteleto Filho frisa que tal processo deve ser concretizado por pessoal especializado, a fim de evitar contaminação com material orgânico (sangue humano) ou inorgânico (tintas, pinturas) localizados no local do crime ou no corpo da vítima ou, igualmente, contaminação com materiais estranhos à prova. Já em relação à confecção do exame, o autor ressalta que é necessário que o expert descreva detalhadamente os métodos que foram utilizados no decorrer da perícia, porquanto, dessa forma, é possível realizar a contraprova ${ }^{63}$ por outro laboratório ${ }^{64}$, bem como efetivar o contraditório pela Defesa.

Aliás, sobre os meios de tornar a perícia de DNA mais segura, cabe citar, dentre todos os mencionados pelo Conselho Nacional de Pesquisa, que a realização da análise por uma segunda pessoa, alheia aos fatos e às amostras, é de grande valor, pois, dessa maneira, é difícil que alguma falha laboratorial passe despercebida ${ }^{65}$.

Em suma, a perícia realizada no DNA não pode ter valor absoluto, sendo somente mais uma prova a integrar o conjunto probatório de um processo ou, ainda, mais um elemento informativo de um inquérito policial. Independentemente do caso, somente será possível acusar ou condenar alguém, existindo provas/elementos suficientes a fim de estabelecer que o material genético do imputado estava presente na vítima ou no local do crime em decorrência desse último; ou seja, o nexo causal ${ }^{66}$ deve ser imperante, conectando o material biológico do imputado com o crime em si.

\section{CONSIDERAÇÕES FINAIS}

\footnotetext{
${ }^{62}$ MARTELETO FILHO, Wagner. O direito à não autoincriminação no processo penal contemporâneo: (investigação genética, interceptações telefônicas e ambientais, agentes infiltrados e outros problemas). Belo Horizonte: Del Rey, 2012, p. 153-154.

${ }^{63}$ Sobre a contraprova por outro laboratório, não se pode olvidar que tal circunstância somente será possível, caso o primeiro laboratório tenha guardado parte do material analisado, o que deve ser feito sempre que possível (CONSELHO NACIONAL DE PESQUISA. A avaliação do DNA como prova forense. Tradução e revisão: F. A. Moura Duarte et al. Ribeirão Preto: FUNPEC, 2001. 283 p. Título original: The evaluation of forensic DNA evidence, p. 101).

${ }^{64}$ MARTELETO FILHO, op. cit., p. 153-154.

${ }^{65}$ CONSELHO NACIONAL DE PESQUISA, op. cit., p. 94.

${ }^{66}$ LOPES JR., Aury. Direito processual penal. 10. ed. São Paulo: Saraiva, 2013, p. 638.
} 
Revista Eletrônica de Direito Processual - REDP.

Rio de Janeiro. Ano 10. Volume 17. Número 2. Julho a Dezembro de 2016

Periódico Semestral da Pós-Graduação Stricto Sensu em Direito Processual da UERJ

Patrono: José Carlos Barbosa Moreira. ISSN 1982-7636. pp. 377-405

www.redp.uerj.br

Os direitos ou garantias fundamentais constantes na Constituição Federal de 1988 não são absolutos e, por isso, podem ser limitados por uma lei processual penal, que deverá, necessariamente, observar os ditames decorrentes da máxima da proporcionalidade tanto na sua feitura quanto na sua aplicação. A Lei n. ${ }^{\circ}$ 12.654/2012, dentre outras alterações, amparada nessa ideia de possibilidade de limitação, restringiu a garantia dos acusados e dos investigados de não se autoincriminar, pois permitiu, inclusive de modo coercitivo, a extração do material biológico para fins de identificação criminal.

Para além do problema formal da novatio legis, que ignora a necessidade de observância da máxima da proporcionalidade, tem-se que o diploma legal fere de modo desproporcional a garantia contra a autoincriminação, tornando-a sem efeito, ou seja, esvaziando seu núcleo essencial, o que não poderia acontecer, notadamente em face de investigados e acusados. Afirma-se isso, porque a Lei traz, na verdade, um meio de prova potencialmente incriminatório e não uma mera identificação criminal. A redação legal estabelece que será realizada perícia do material biológico coletado do imputado, caso o perfil genético coincida com o do DNA localizado na vítima ou no local do crime, sendo que o primeiro material poderá ser coletado inclusive sem o consentimento do identificado. Portanto, conforme o novo diploma, o agente poderá ser submetido à extração do seu material biológico, de modo consentido ou forçado, para fins de identificação criminal, mas, se houver a compatibilidade mencionada, será confeccionado um laudo pericial, que conterá a afirmação de que, no mínimo, o agente esteve junto com a vítima, acarretando, consequentemente, na confecção de uma prova que poderá levar a uma condenação. Em nenhum momento, como se pode ver, houve a possibilidade de o indivíduo se negar a produzir tal prova, pois essa será feita, seja com ou sem o seu consentimento.

Logo, diante dessa situação caótica, sustenta-se que o mais adequado é o estabelecimento da imprescindibilidade do consentimento do sujeito a ser identificado, a fim de manter todos os direitos do cidadão e evitar que uma Lei redigida de forma equivocada prevaleça e elimine com a garantia fundamental a não autoincriminação. É essencial a ideia de que a prova genética, mesmo que produzida com o consentimento do indivíduo, não possa ser a única base de uma condenação, visto que tal exame é passível de erro laboratorial e, ainda, traz somente uma probabilidade de que certa pessoa esteve com a vítima ou no local do delito, o que não traduz, com $100 \%$ de certeza, a autoria criminosa. 
Revista Eletrônica de Direito Processual - REDP.

Rio de Janeiro. Ano 10. Volume 17. Número 2. Julho a Dezembro de 2016

Periódico Semestral da Pós-Graduação Stricto Sensu em Direito Processual da UERJ

Patrono: José Carlos Barbosa Moreira. ISSN 1982-7636. pp. 377-405

www.redp.uerj.br

A prova de DNA, então, desde que feita com o consentimento do agente, é apenas mais uma prova dentro de um processo, não podendo conduzir, sozinha, a uma condenação.

\section{REFERÊNCIAS BIBLIOGRÁFICAS}

CANOtilho, J. J. Gomes. Direito constitucional e teoria da Constituição. 7. ed. Coimbra: Almedina, 2003. 1522 p.

CAPEZ, Fernando. Curso de processo penal. 21. ed. São Paulo: Saraiva, 2014. 892 p.

CONSELHO NACIONAL DE PESQUISA. A avaliação do DNA como prova forense. Tradução e revisão: F. A. Moura Duarte et al. Ribeirão Preto: FUNPEC, 2001. 283 p. Título original: The evaluation of forensic DNA evidence.

FIORI, Ariane Trevisan. Os direitos individuais e a intervenção corporal: a necessária releitura constitucional como forma de efetivação dos direitos fundamentais. In: CONGRESSO NACIONAL MANAUS, 15., 2006, Manaus. Anais... Manaus: CONPEDI/UEA, $2006 . \quad$ Disponível em: $<$ http://www.conpedi.org.br/manaus/arquivos/anais/manaus/hermeneutica_ariane trevisan fiori.pdf>. Acesso em: 09 mar. 2015.

GIACOMOLLI, Nereu José. $O$ devido processo penal: abordagem conforme a Constituição Federal e o Pacto de São José da Costa Rica. São Paulo: Atlas, 2014. 406 p.

JOBIM, Luiz Fernando; COSTA, Luíz Renato; SILVA, Moacir da. Identificação humana: identificação médico legal, perícias odontolegais, identificação humana pelo DNA. 2. ed. Campinas: Millennium Editora, 2012. 276 p.

LIMA, Renato Brasileiro de. Manual de processo penal. 2. ed. rev. atual. ampl. Salvador: Jus Podivm, 2014. 1760 p. 
Revista Eletrônica de Direito Processual - REDP.

Rio de Janeiro. Ano 10. Volume 17. Número 2. Julho a Dezembro de 2016

Periódico Semestral da Pós-Graduação Stricto Sensu em Direito Processual da UERJ

Patrono: José Carlos Barbosa Moreira. ISSN 1982-7636. pp. 377-405

www.redp.uerj.br

LOPES JR., Aury. Direito processual penal. 10. ed. São Paulo: Saraiva, 2013. 1394 p.

LOPES JR., Aury. Lei 12.654/2012: é o fim do direito de não produzir prova contra si mesmo (nemo tenetur se detegere)? Boletim IBCCRIM, São Paulo, ano 20, n. 236, p. 5-6, jul. 2012.

LOPES JR., Aury. Sistemas de investigação preliminar no processo penal. 3. ed. rev. ampl. atual. Rio de Janeiro: Lumen Juris, 2005. 384 p.

MARTELETO FILHO, Wagner. $O$ direito à não autoincriminação no processo penal contemporâneo: (investigação genética, interceptações telefônicas e ambientais, agentes infiltrados e outros problemas). Belo Horizonte: Del Rey, 2012. 272 p.

NICOLITT, André. Banco de dados de perfis genéticos (DNA): as inconstitucionalidades da Lei 12.654/2012. Boletim IBCCRIM, São Paulo, ano 21, n. 245, p. 15-16, abr. 2013.

OLIVEIRA, Eugênio Pacelli de. Curso de processo penal. 12. ed. Rio de Janeiro: Lumen Juris, 2009. 884 p.

OLIVEIRA, Eugênio Pacelli de. Curso de processo penal. 17. ed. São Paulo: Atlas, 2013. $1013 \mathrm{p}$.

QUEIJO, Maria Elizabeth. O direito de não produzir prova contra si mesmo: o princípio nemo tenetur se detegere e suas decorrências no processo penal. 2. ed. São Paulo: Saraiva, 2012. 518 p.

QUEIJO, Maria Elizabeth. O princípio nemo tenetur se detegere e a coleta de material genético: identificação criminal ou colaboração na produção da prova? Boletim IBCCRIM, São Paulo, ano 21, n. 250, p. 7-9, set. 2013. 
Revista Eletrônica de Direito Processual - REDP.

Rio de Janeiro. Ano 10. Volume 17. Número 2. Julho a Dezembro de 2016

Periódico Semestral da Pós-Graduação Stricto Sensu em Direito Processual da UERJ

Patrono: José Carlos Barbosa Moreira. ISSN 1982-7636. pp. 377-405

www.redp.uerj.br

SAUTHIER, Rafael. A identificação e a investigação criminal genética à luz dos direitos fundamentais e da Lei 12.654/12. 2013. 251 f. Dissertação (Mestrado em Ciências Criminais) - Faculdade de Direito, Pontifícia Universidade Católica do Rio Grande do Sul, Porto Alegre, 2013.

SILVA, Rodrigo Vaz. Princípio da legalidade, direitos fundamentais e máxima da proporcionalidade: análise da obrigatoriedade de submissão ao exame de DNA no ordenamento jurídico-penal brasileiro. 2013. 175 f. Dissertação (Mestrado em Ciências Criminais) - Faculdade de Direito, Pontifícia Universidade Católica do Rio Grande do Sul, Porto Alegre, 2013.

VAY, Giancarlo Silkunas; SILVA, Pedro José Rocha e. A identificação criminal mediante coleta de material biológico que implique intervenção corporal e o princípio do nemo tenetur se detegere. Boletim IBCCRIM, São Paulo, ano 20, n. 239, p. 13-14, out. 2012. 